\title{
THE CONSEQUENCES OF LOCALISED CHROMOSOME BREAKAGE
}

\author{
JOHN MCLEISH \\ John Innes Horticultural Institution, Hertford, Herts.
}

Received 8.x.53

\section{INTRODUCTION}

Chromosomes can be broken by various chemical reagents in specific regions and at specific times during the mitotic cycle. With 8-ethoxycaffeine (EOG) and maleic hydrazide ( $\mathrm{MH}$ ) breaks and re-arrangements are induced in the resting nucleus and are first observed at the ensuing mitosis (Kihlman and Levan, 195I ; McLeish, I952 ; see plate, figs. I and 2). The consequences of these limited and regular effects in succeeding cell generations have now been studied in an attempt to answer the following questions :

(i) After breakage at different positions, can the acentric fragments and the micronuclei that they form be classified into recognisable groups?

(ii) Does the loss or gain of specific parts of nuclei tell us anything about their structure and the elements necessary for their survival ?

(iii) To what extent can the centric and acentric products of primary breakage be used as markers for timing new breakage and reunion in later resting nuclei ?

\section{MATERIALS AND METHODS}

Seedlings of Vicia faba var. Claudia Aquadulce were used in the present experiments. I have already described the methods used in their growth and treatment (1952).

MH treatment. - A dose was selected which, while giving a high breakage frequency, subsequently allowed growth and mitosis to continue so that later cell generations could be studied :

$$
0.5 \mathrm{mM} / 2 \mathrm{hrs} .20^{\circ} \mathrm{C} \text {. }
$$

EOC treatment.*-A dose similar to that employed by Kihlman and Levan (195I) was found suitable in these respects :

$$
8 \mathrm{mM} / 8 \mathrm{hrs} . / 7^{\circ} \mathrm{C} \text {. }
$$

In this case, the plants were kept at $7^{\circ} \mathrm{C}$. for 2 days prior to treatment and afterwards were allowed to recover at $20^{\circ} \mathrm{C}$.

Preparations.-For metaphase :-

(i) Pre-treatment : Normally, 2 hours in 0.05 per cent. colchicine. In the EOC experiments, breaks in the nucleolar constriction were more easily detected if the chromosomes were excessively contracted so that the acentric fragments became free. Pre-treatment was therefore extended to 4 hours.

* I should like to thank Dr B. Kihlman for his gift of a sample of EOC. 385 
(ii) Fixation : 2 BD overnight.

(iii) Post-fixation: The roots were washed in distilled water and then softened and bleached for 10 mins. in a mixture of ammonium oxalate (sat. aq. soln.) and hydrogen peroxide (20 vol.) I : I (Dr G. E. Ford, private communication).

(iv) Staining : Feulgen squash method.

For anaphase :-This same technique was used but pre-treatment was omitted.

For studying the positions of acentric fragments and micronuclei :-

(i) Fixation : $2 \mathrm{BD}$ overnight.

(ii) Embedding : $52^{\circ}$ G. M.P. paraffin wax.

(iii) Sectioning : at $20 \mu$.

(iv) Staining : iodine-crystal violet method.

For nucleoli :-A. Sections.

(i) Fixation : $1: 3$ acetic alcohol.

(ii) Embedding : $52^{\circ}$ C. M.P. paraffin wax.

(iii) Sectioning : at $6 \mu$.

(iv) Staining : methyl green-pyronin (Kurnick, 1952).

B. Squashes.

(i) Fixation : formalin-chromic acid overnight (Lewitsky, 1931).

(ii) Staining : Feulgen-light green (Semmens and Bhaduri, I94I).

Measurements.-Outline camera-lucida drawings of nuclei and nucleoli were made at a magnification of $\times 2520$. Their areas were then computed from counts made on a superimposed grid of $1 / 16$ in. squares for nuclei and, to reduce error, $1 / 32$ in. squares for the smaller nucleoli.

Scoring and mapping of breaks.-The symbols of Darlington and La Cour (1945) were used in scoring structural changes. The positions of breaks were mapped by camera-lucida drawings and checked, where possible, by comparisons with the lengths of undamaged homologues.

Detection of later cell generations $\left(\mathrm{X}_{2}-\mathrm{X}_{\mathrm{n}}\right)$.- The progeny of damaged cells were recognised by the occurrence of any one of the following :-

(i) micronuclei ;

(ii) deficiency or translocation of chromosome parts ;

(iii) reproduced acentrics ;

(iv) chromosome reunion ( $\left.R^{\prime \prime}\right)$ giving dicentric chromosomes-a reunion which very rarely occurs at $\mathrm{X}_{1}$ (McLeish, 1952).

\section{CLASSIFICATION OF ACENTRICS AND MICRONUCLEI}

The action of EOG and MH in Vicia is to induce limited and localised breakage, EOC chiefly in the nucleolar constriction, $\mathrm{MH}$ in the heterochromatin. Its distribution is shown in graphs 1 and 5 . Characteristic acentric fragments and micronuclei are thus produced especially by the breakage of the $\mathrm{M}$ chromosome.

Acentrics.-Because of the positions of breakage, only four main types of acentric fragment need concern us. They are classified according to the way in which euchromatin, heterochromatin and nucleolar organisers are combined or separated (fig. I). At $\mathbf{X}_{1}$ telophase they may be included in main nuclei or lost. If included, all types retain their individuality throughout the ensuing resting stage and reproduce along with the centric chromosomes at $\mathbf{X}_{2}$ (plate, fig. 7). If lost, they constitute micronuclei of characteristic form. 


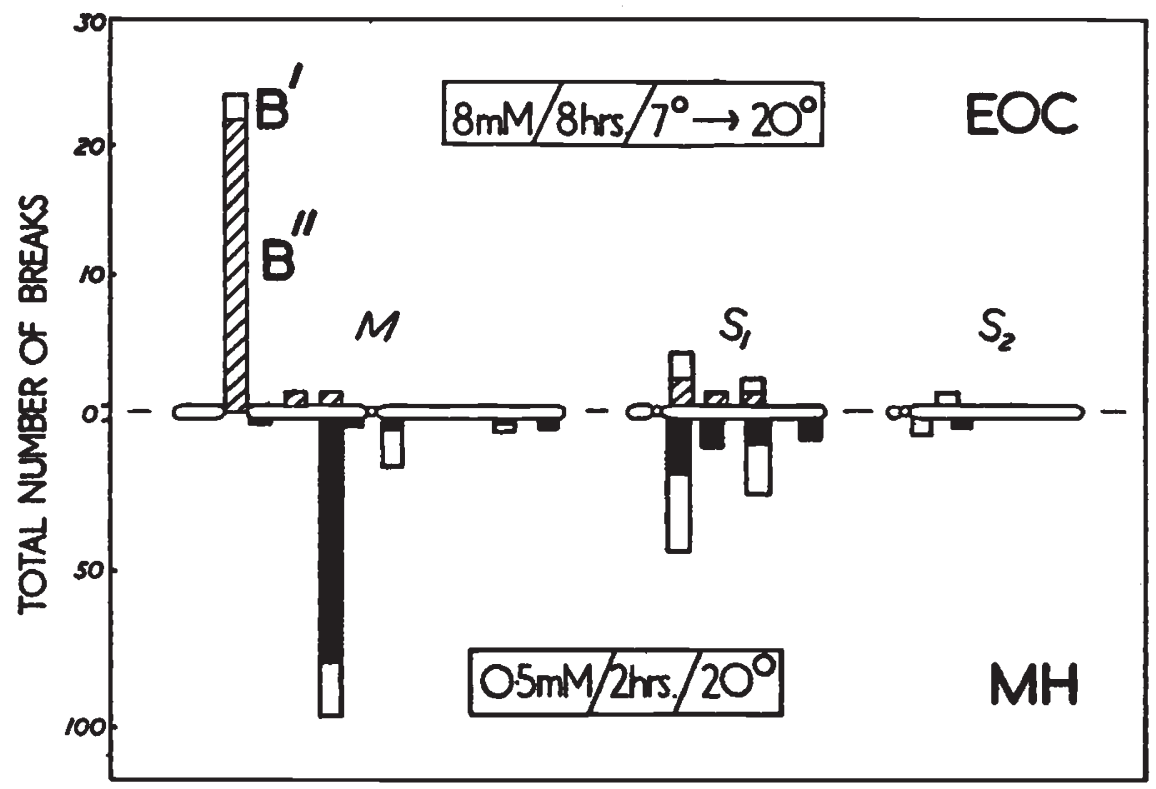

GrAPH I.-Comparison of the distribution of breakage segments, in $X_{1}$ cells, in the 3 chromosome types $M, S_{1}$ and $S_{2}$; one day after treatment with EOC (above) and up to and including 5 days after treatment with $\mathrm{MH}$ (below). Tabular data not given for EOC. MH data from McLeish (1952), table 4.

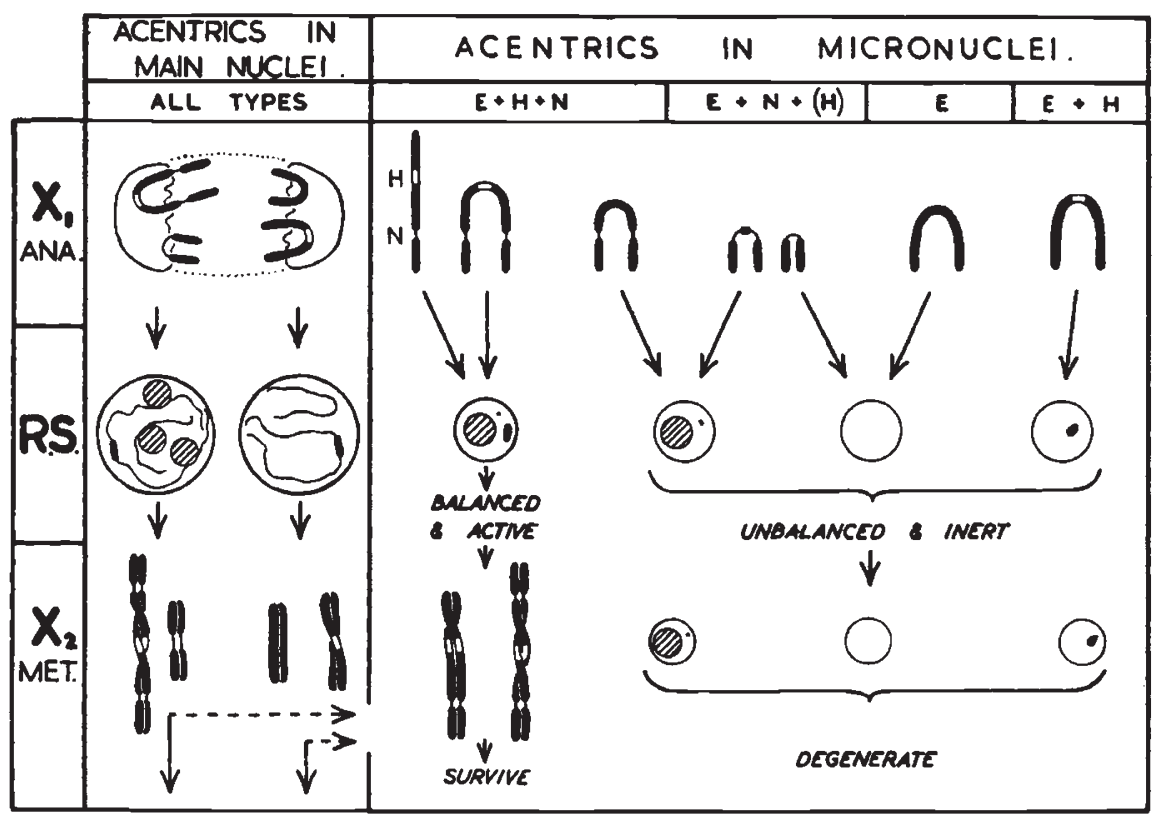

Fig. 1.-Diagram showing how the 4 main groups of acentrics, with various combinations of euchromatin $(E)$, heterochromatin $(\mathrm{H})$, and nucleolar organisers $(\mathrm{N})$, behave when included in main nuclei or micronuclei. The inferred small heterochromatic segment near the nucleolar organiser is not represented. R.S.-resting stage. 
Nucleolar organisers are marked by secondary constrictions at mitosis and are thus detectable in acentrics. They organise nucleoli in micronuclei. Heterochromatic segments are, of course, indistinguishable from the euchromatin at mitosis under normal temperature conditions. But they betray their presence in micronuclei by their typical allocyclic behaviour. They are then visible as Feulgen-positive chromocentres (fig. 4, a-d ; see also Darlington and La Cour, I940, I94I).

Nearly all acentrics in Vicia arise in one of two ways : from $B^{\prime \prime} S R$ or $B^{\prime} R^{\prime}$ (fig. 2). Those arising from $B^{\prime \prime} S R$ are iso-acentrics. They are double since the arms on each side of the point of reunion are derived from sister chromatids. As we shall see, the extent of such duplication as well as of translocation $\left(B^{\prime} R^{\prime}\right)$ in acentrics, influences both the structure and subsequent behaviour of their micronuclei.

\begin{tabular}{|c|c|c|}
\hline \multicolumn{2}{|c|}{ B. SR. } & B. R.' \\
\hline & \\
\hline
\end{tabular}

Fro. 2.-Diagram showing how the amount of heterochromatin $(\mathrm{H})$, carried by acentrics with nucleolar organisers $(\mathrm{N})$, can be determined by both the position and the type of breakage and reunion.

Micronuclei.-The contents of micronuclei formed after random $\mathrm{X}$-ray breakage must remain largely unknown unless displayed during a further mitosis. On the other hand, localised chemical breakage can provide a method of segregating known parts of the nucleus as standard acentrics in micronuclei. These, and their complementary but now deficient main nuclei can be examined in some detail.

I have accordingly made measurements of main nuclei, micronuclei and their nucleoli in selected cells of the type shown in fig $4 a$ which occur 24 hours after $\mathrm{MH}$ treatment. They are daughter cells derived from an $\mathrm{X}_{1}$ mitosis in which most of the nucleolar arm of one $\mathrm{M}$ chromosome had been lost from the nucleus but included in the cell. Their contents can be inferred from the observed breakage 
occurring up to 24 hours. This is of low frequency with high localisation in segment 2 (graph 5 ; see also McLeish, 1952, tables 2 and 4 ). Moreover 94 per cent. of these breaks are $B^{\prime \prime}$-s followed by SR to give nucleolar iso-acentrics (fig. 2). Thus the majority of micronuclei selected for measurement contain two sister nucleolar organisers and their main nuclei only one. Nucleoli are organised in both.

At the time of fixation (i.e. 24 hours) most micronuclei are less than I2 hours old. This is because, as I previously showed, most breakage appears in mitosis more than 12 hours after treatment. Their size and structure are then accurate indicators of their constitution since any variability due to their survival or degeneration is not yet likely to be apparent.

For comparison, I measured those cells ( $45^{\circ} 9$ per cent.) in untreated roots where the products of the two organisers had fused to give a single nucleolus.

The results of all these measurements are given in graph 2 and are discussed in the next section.

\section{THE ORGANISATION OF NUCLEOLI IN VICIA}

A study of the positions and products of localised breakage can give us an idea of the position of origin of nucleoli and the factors controlling their size.

Position of origin.-The evidence concerning nucleolar origin in Vicia is derived from the two types of localised breakage (with EOG and $\mathrm{MH}$ ) and from observations on $\mathrm{X}_{2}$ cells.

The positions of breakage with EOG are shown in graph I. $88 \cdot 2$ per cent. of the resulting acentrics carry varying lengths of the nucleolar constriction (plate, fig. I) yet only I 3.5 per cent. of the total micronuclei have nucleoli (table I). These micronuclei are approximately the same size as those seen in MH-treated cells (fig. $4 a$; plate, fig. 3). They are probably formed by acentrics derived from the 6.5 per cent. of breaks occurring between the organiser and the centromere. The production of a nucleolus would then depend not on the constriction region as a whole but on some locus at its proximal end.

The constriction or "SAT zone," observed at mitosis, has often been supposed to be the result of nucleolar growth during the preceding telophase and resting stage. This was suggested by the observations of McClintock (1934) in Zea Mays and Navashin (1934) in Crepis. The suggestion can be tested in Vicia by observing the behaviour of nucleolar acentrics in micronuclei. As we shall see, some of these remain viable; they reproduce and reappear at $\mathrm{X}_{2}$ (fig. 6 ; plate, figs. 2 to 5). We then see that the lengths of their nucleolar constrictions are not significantly diminished despite the fact that much smaller nucleoli were formed at the preceding telophase. Possibly the difference in nucleolar size is insufficient to give detectable 
TABLE I

Frequencies of nucleolar and non-nucleolar acentrics and micronuclei at different times after EOC treatment. Scored at $X_{1}$ metaphase and anaphase, during the resting stage (R.S.) and at $X_{n}$ prophase. Nucleolar acentrics are those with nucleolar constrictions

\begin{tabular}{|c|c|c|c|c|}
\hline Time & Cells & $\begin{array}{l}\text { Per cent. with } \\
\text { acentrics }\end{array}$ & $\begin{array}{c}\text { Total } \\
\text { nucleolar }\end{array}$ & $\begin{array}{c}\text { Total } \\
\text { non-nucleolar }\end{array}$ \\
\hline I D & $\begin{array}{l}\text { Met. } 60 \\
\text { Ana. } 100\end{array}$ & $\begin{array}{l}40 \cdot 0 \\
44^{\circ} 0\end{array}$ & $\begin{array}{l}25 \\
4^{8}\end{array}$ & $\begin{array}{l}2 \\
8\end{array}$ \\
\hline \multirow[t]{2}{*}{$2 \mathrm{D}$} & Ana. 25 & 8.0 & 2 & $\cdots$ \\
\hline & & $\begin{array}{l}\text { Total } \\
\text { Per cent. }\end{array}$ & $\begin{array}{c}75 \\
88 \cdot 2\end{array}$ & $\begin{array}{r}10 \\
I I \cdot 8\end{array}$ \\
\hline
\end{tabular}

R.S.

\begin{tabular}{|c|c|c|c|c|}
\hline Time & $\begin{array}{c}\text { Resting } \\
\text { cells }\end{array}$ & $\begin{array}{c}\text { Per cent. with } \\
\text { micronuclei }\end{array}$ & $\begin{array}{c}\text { Total } \\
\text { nucleolar }\end{array}$ & $\begin{array}{c}\text { Total } \\
\text { non-nucleolar }\end{array}$ \\
\hline 2 D & 737 & $5 \cdot 4$ & 5 & 36 \\
3 D & 651 & $2 \cdot 6$ & 3 & 16 \\
4 D & 635 & $2 \cdot 2$ & 2 & 12 \\
\hline & & $\begin{array}{l}\text { Total } \\
\text { Per cent. }\end{array}$ & $13 \cdot 5$ & 64 \\
\hline
\end{tabular}

$\mathbf{X}_{\mathbf{n}}$

\begin{tabular}{|c|c|c|c|c|c|c|}
\hline \multirow{2}{*}{ Time } & \multirow{2}{*}{ Prophase cells } & \multirow{2}{*}{$\begin{array}{l}\text { Per cent. with } \\
\text { micronuclei }\end{array}$} & \multicolumn{2}{|c|}{$\begin{array}{c}\text { Total } \\
\text { nucleolar }\end{array}$} & \multicolumn{2}{|c|}{$\begin{array}{c}\text { Total } \\
\text { non-nucleolar }\end{array}$} \\
\hline & & & Active & Inert & Active & Inert \\
\hline $2 \mathrm{D}$ & 712 & $5 \cdot 6$ & I & 3 & $\cdots$ & 38 \\
\hline $3 \mathrm{D}$ & 983 & $0.6 r$ & $\cdots$ & $\cdots$ & $\cdots$ & 6 \\
\hline \multirow[t]{2}{*}{${ }_{4} D$} & 947 & $I \cdot I$ & $\ldots$ & 1 & $\ldots$ & Io \\
\hline & & $\underset{\text { Per cent. }}{\text { Total }}$ & $\begin{array}{c}1 \\
1 \cdot 7\end{array}$ & $\begin{array}{c}4 \\
6 \cdot 9\end{array}$ & $\cdots$ & $\begin{array}{r}54 \\
9 r \cdot 4\end{array}$ \\
\hline
\end{tabular}


differences in constriction length at the ensuing mitosis. On the other hand, the nucleolar constriction of Vicia may be a segment of constant length, which, in conjunction with an adjoining proximal locus, forms a compound organiser gene. The constriction could be regarded as a part of the chromosome which is necessary for the proper functioning of the organiser and around which the substances of the nucleolus are secreted (fig. 3).

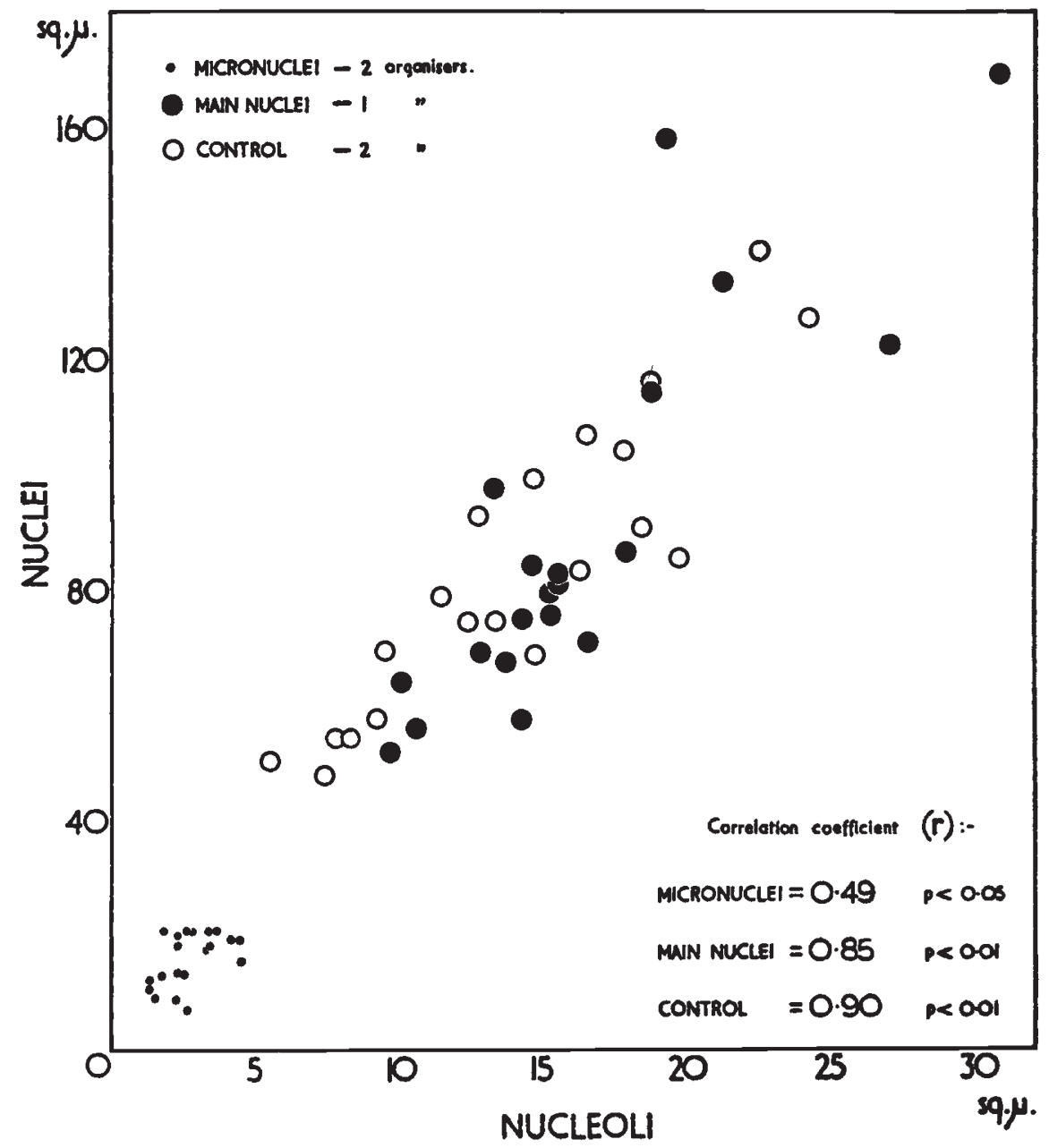

GRAPH 2.-Showing the linear correlations between nuclear and nucleolar size in the 3 selected classes. Tabular date not given.

Occasionally, in MH-treated diploid cells of Vicia, more than two nucleoli appear (fig. 4c). Most of these cases probably result from the inclusion in daughter cells at $\mathrm{X}_{1}$ of extra nucleolar organisers carried by acentrics. Others, as we shall see, appearing 2 days or more after treatment, can be the result of reproduction of such acentrics.

As Heitz (I93I) originally suggested, other chromosomes may 
have the ability to organise nucleoli. Darlington and Haque (1954) have obtained additional evidence of this from the structure of microcytes at the second meiotic division of Allium. In the present experiments with Vicia I think such behaviour must be rare for two reasons. First, more than two nucleoli never appear in normal Vicia cells; and secondly, in MH-treated cells, the relative frequency of nucleolar and non-nucleolar acentrics at mitosis 24 hours after treatment agrees, approximately, with the relative frequency of their corresponding micronuclei at this time (table 2).

Size.-The following results were obtained from measurements made in the types of selected cells described in the previous section :

(i) There is a significant linear correlation between nuclear and nucleolar size in each of the three classes considered (graph $2 ; c f$. Fernandes and Serra, 1944). The scatter may be due to the nuclei being in different physiological stages of interphase since a similar correlation has been observed by Lesher (195I) during increases of chromosome size in salivary gland nuclei of Drosophila.

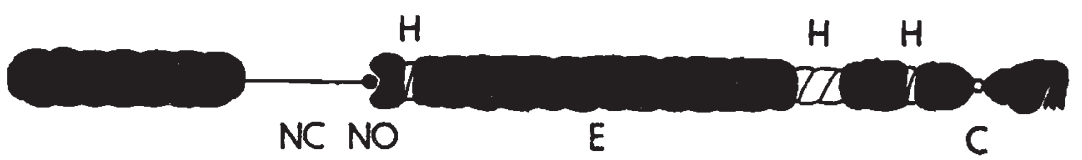

FIG. 3.-Diagram showing the way in which the euchromatin (E), heterochromatin (H) and nucleolar organiser (NO) may be distributed in the nucleolar arm of the $\mathbf{M}$ chromosome of Vicia faba. C-centromere ; NC-nucleolar constriction. The large heterochromatic segment can be revealed by cold treatment. The positions of the two smaller ones are inferred.

(ii) The single nucleolus of the micronucleus is the product of two organisers yet is always smaller than that of its accompanying main nucleus which is the product of one. These latter nucleoli fall into the same range of size as those of controls which are the fusion products of two organisers (graph 2).

(iii) Only 6.6 per cent. of the total micronuclei occurring 24 hours after treatment contain two separate nucleoli in contrast to the $54^{-I}$ per cent. of controls. The separate nucleoli are then further reduced in size (fig. $4 b$ ). Nucleolar fusion here must be due partly to the frequent proximity of sister organisers in iso-acentrics derived from B" SR (fig. 2), and partly to the restricted internal volume of the micronuclei.

Together, I think these data confirm the general conclusions of McClintock (1934) in showing the size of nucleoli to be influenced by three factors : by competition between their organisers, by the amount of chromosome material which surrounds the organisers, and by the existing physiological condition of their nuclei. 
TABLE 2

Frequencies of cells with nucleolar and non-nucleolar acentrics and micronuclei at different times after $M H$ treatment. Scored at $X_{1}$ metaphase, during the resting stage (R.S.) and at $X_{n}$ prophase. Nucleolar acentrics are those with nucleolar constrictions. Reproduced in graph 3 .

\begin{tabular}{|c|c|c|c|c|c|c|c|c|}
\hline Time & $\begin{array}{l}\text { Meta- } \\
\text { phase } \\
\text { cells }\end{array}$ & $\begin{array}{l}\text { Per cent. } \\
\text { with } \\
\text { acentrics }\end{array}$ & $\begin{array}{c}\text { Nucleo- } \\
\text { lar }\end{array}$ & $\begin{array}{l}\text { Per } \\
\text { cent. }\end{array}$ & $\begin{array}{l}\text { Non- } \\
\text { nucleo- } \\
\text { lar }\end{array}$ & $\begin{array}{l}\text { Per } \\
\text { cent. }\end{array}$ & $\begin{array}{l}\text { Both } \\
\text { types }\end{array}$ & $\begin{array}{l}\text { Per } \\
\text { cent. }\end{array}$ \\
\hline $\begin{array}{ll}1 & D \\
2 & D \\
3 & D\end{array}$ & $\begin{array}{r}50 \\
200 \\
200\end{array}$ & $\begin{array}{l}18 \cdot 0 \\
31 \cdot 0 \\
23 \cdot 0\end{array}$ & $\begin{array}{r}5 \\
32 \\
26\end{array}$ & $\begin{array}{l}55 \cdot 6 \\
5 I \cdot 6 \\
56 \cdot 5\end{array}$ & $\begin{array}{r}4 \\
20 \\
15\end{array}$ & $\begin{array}{l}44 \cdot 4 \\
32 \cdot 3 \\
32 \cdot 6\end{array}$ & $\begin{array}{r}\ldots \\
10 \\
5\end{array}$ & $\begin{array}{l}\ddot{r} \cdot r \\
r 0 \cdot 9\end{array}$ \\
\hline
\end{tabular}

R.S.

\begin{tabular}{|c|c|c|c|c|c|c|c|c|}
\hline Time & $\begin{array}{l}\text { Resting } \\
\text { cells }\end{array}$ & $\begin{array}{c}\text { Per cent. } \\
\text { with } \\
\text { micro- } \\
\text { nuclei }\end{array}$ & $\begin{array}{c}\text { Nucleo- } \\
\text { lar }\end{array}$ & $\begin{array}{c}\text { Per } \\
\text { cent. }\end{array}$ & $\begin{array}{l}\text { Non- } \\
\text { nucleo- } \\
\text { lar }\end{array}$ & $\begin{array}{c}\text { Per } \\
\text { cent. }\end{array}$ & $\begin{array}{l}\text { Both } \\
\text { types }\end{array}$ & $\begin{array}{c}\text { Per } \\
\text { cent. }\end{array}$ \\
\hline $\begin{array}{ll}1 & D \\
2 & D \\
3 & D \\
4 & D \\
5 & D \\
6 & D \\
7 & D\end{array}$ & $\begin{array}{l}5673 \\
2025 \\
2487 \\
2482 \\
2231 \\
1839 \\
1178\end{array}$ & $\begin{array}{r}0.8 \\
r 0 \cdot 9 \\
r 6 \cdot 7 \\
r 4.5 \\
8 \cdot 4 \\
2 \cdot 8 \\
2 \cdot 3\end{array}$ & $\begin{array}{r}24 \\
101 \\
180 \\
111 \\
45 \\
21 \\
15\end{array}$ & $\begin{array}{l}53 \cdot 3 \\
45 \cdot 9 \\
43 \cdot 4 \\
30 \cdot 7 \\
23 \cdot 9 \\
40 \cdot 4 \\
55 \cdot 5\end{array}$ & $\begin{array}{r}20 \\
110 \\
219 \\
238 \\
138 \\
29 \\
11\end{array}$ & $\begin{array}{l}44 \cdot 4 \\
50 \cdot 0 \\
52 \cdot 8 \\
65 \cdot 9 \\
73 \cdot 4 \\
55 \cdot 8 \\
40.7\end{array}$ & $\begin{array}{r}1 \\
9 \\
16 \\
12 \\
5 \\
2 \\
1\end{array}$ & $\begin{array}{l}2 \cdot 2 \\
4 \cdot 1 \\
3 \cdot 8 \\
3 \cdot 3 \\
2 \cdot 7 \\
3 \cdot 8 \\
3 \cdot 8\end{array}$ \\
\hline
\end{tabular}

$\mathbf{X}_{\mathbf{n}}$

\begin{tabular}{|c|c|c|c|c|c|c|}
\hline \multirow{2}{*}{ Time } & \multirow{2}{*}{$\begin{array}{l}\text { Prophase } \\
\text { cells }\end{array}$} & \multirow{2}{*}{$\begin{array}{c}\text { Per cent. with } \\
\text { micronuclei }\end{array}$} & \multicolumn{2}{|c|}{ Total nucleolar } & \multicolumn{2}{|c|}{ Total non-nucleolar } \\
\hline & & & Active & Inert & Active & Inert \\
\hline \multirow[t]{2}{*}{$\begin{array}{l}3 \mathrm{D} \\
4 \mathrm{D} \\
5 \mathrm{D}\end{array}$} & $\begin{array}{r}557 \\
794 \\
1023\end{array}$ & $\begin{array}{l}6 \cdot I \\
4 \cdot 9 \\
I \cdot 3\end{array}$ & $\begin{array}{l}12^{*} \\
20^{\dagger} \\
4 \ddagger\end{array}$ & $\begin{array}{l}7 \\
8 \\
1\end{array}$ & $\begin{array}{l}\cdots \\
\cdots \\
\cdots\end{array}$ & $\begin{array}{r}15 \\
11 \\
8\end{array}$ \\
\hline & & $\begin{array}{l}\text { Total } \\
\text { Per cent. }\end{array}$ & $\begin{array}{c}36 \\
4 r \cdot 9\end{array}$ & $\begin{array}{l}16 \\
18 \cdot 6\end{array}$ & $\begin{array}{l}\cdots \\
\cdots\end{array}$ & $\begin{array}{c}34 \\
39 \cdot 5\end{array}$ \\
\hline
\end{tabular}

* One in advance of main nucleus.

$\dagger$ One retarded slightly.

$\ddagger$ One cell contained two. 


\section{THE BEHAVIOUR OF ACENTRICS IN MICRONUCLEI}

We have already seen how acentrics can be classified into recognisable groups, each forming characteristic micronuclei. A study of the frequency and behaviour of these micronuclei at various times after their formation shows that they are mostly lost. Of those
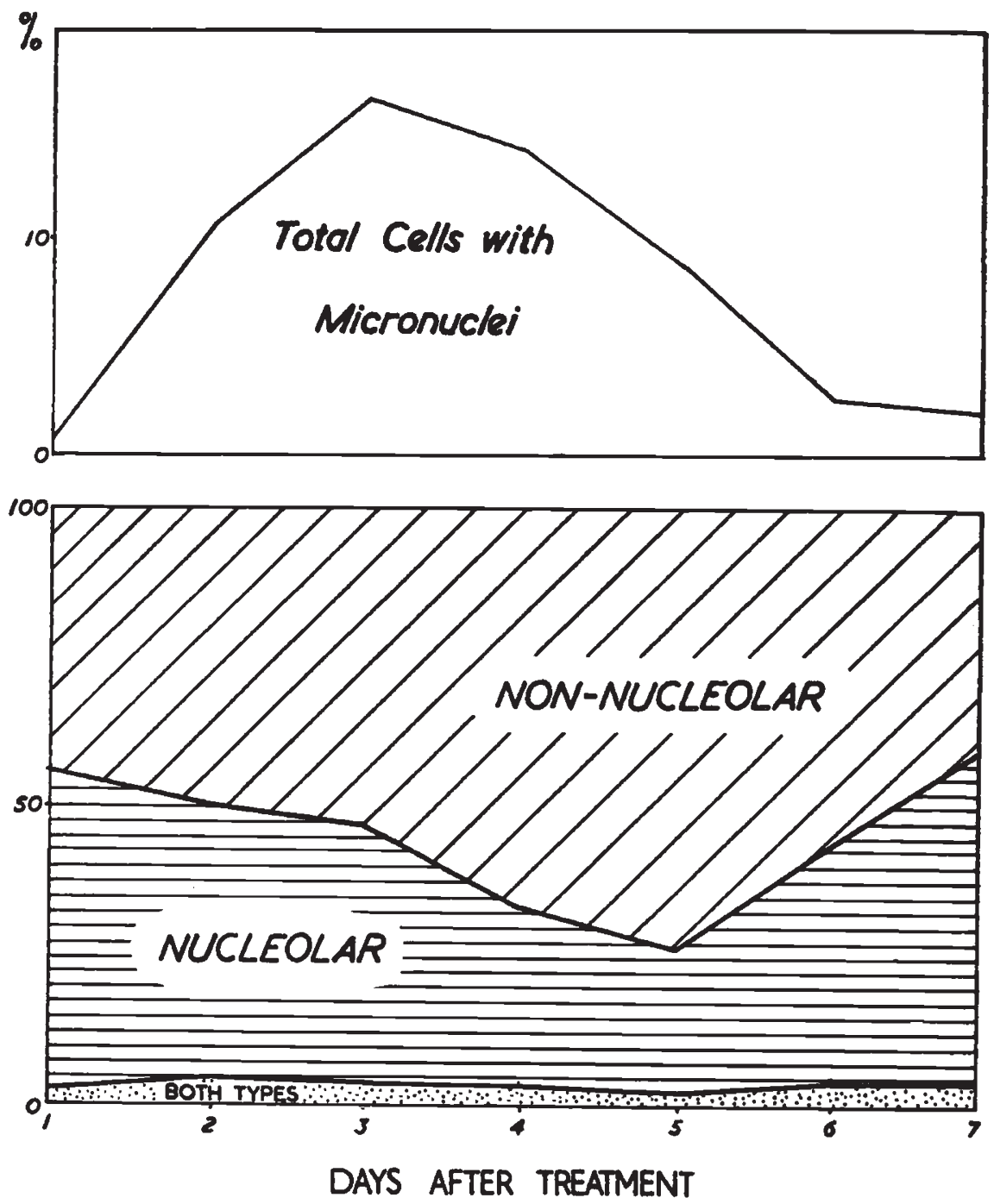

GRAPH 3.-Frequencies of resting cells containing micronuclei at different times after MH treatment. From table 3.

that survive, some appear to be able to play an active part in cell metabolism.

Elimination of micronuclei.-Two main factors operate in eliminating micronuclei from the root meristem. Some degenerate and are absorbed into the cytoplasm or into the main nucleus, while others 
are carried away from the apex into differentiated tissue by growth and mitosis. After $\mathrm{MH}$ treatment a few new micronuclei continue to arise as a result of deferred breakage. But these are insufficient to interfere with the quantitative estimates of those of primary origin. A small proportion of micronuclei are presumably retained for variable

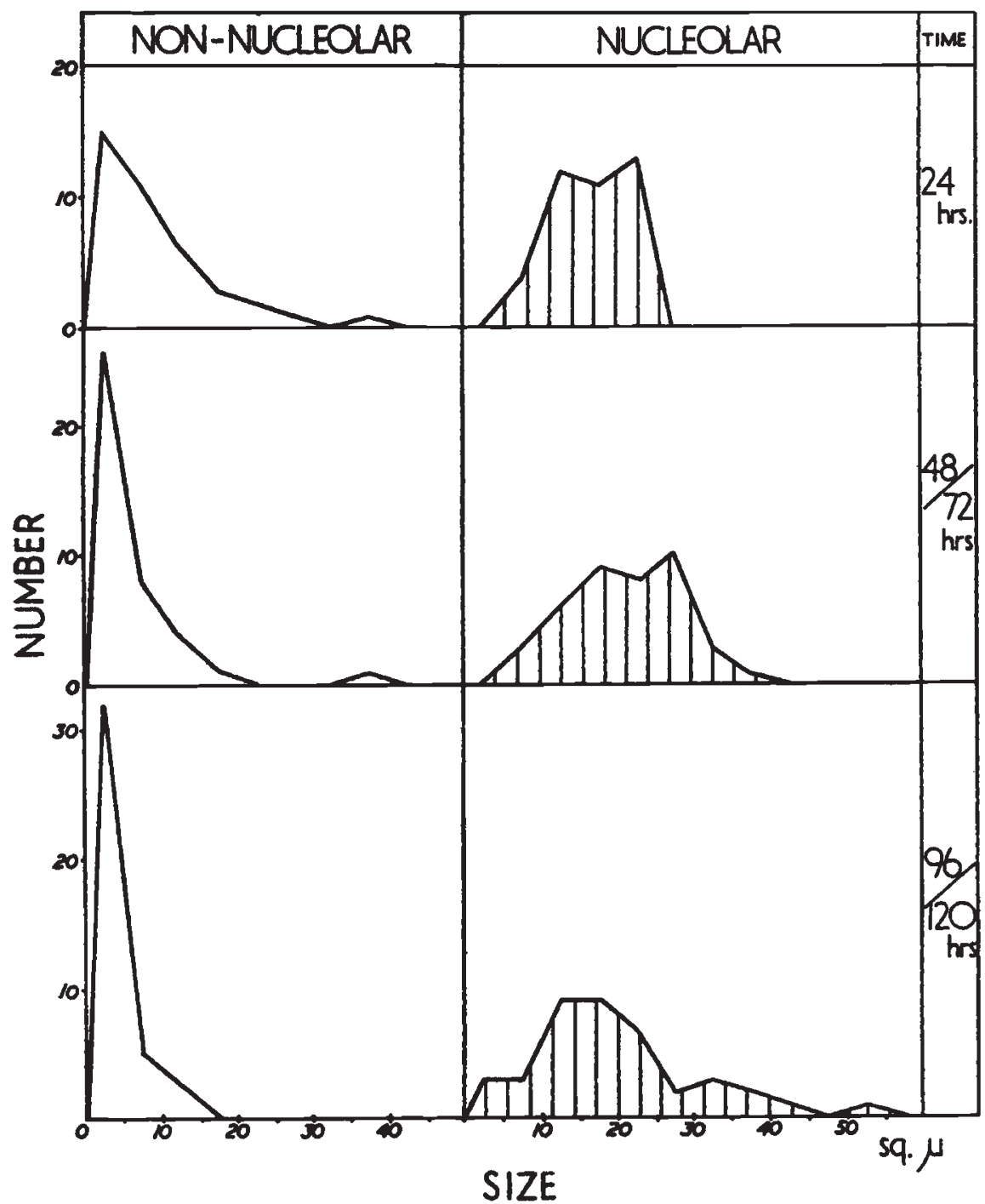

Graph 4.-Comparison of the sizes of nucleolar and non-nucleolar micronuclei at different times after MH treatment. 40 micronuclei of each type were measured for each of the 3 comparisons (the 48 and $72 \mathrm{hrs}$. and the 96 and $120 \mathrm{hrs}$. data showed no significant difference and were lumped). Tabular data not given.

times in the meristem by being carried forward in mitosis. The survivors of this proportion must be mostly nucleolar since in contrast to non-nucleolar types, their frequency rises again after 5 days (table 2, graph 3). This conclusion is confirmed in graph 4. Here, 
the distinction between the two types is expressed as a size difference. For, while the non-nucleolar micronuclei continually decrease in size with time, the nucleolar types exhibit a greater variability. A spread occurs, representing, as we shall see from other evidence, degeneration in one direction, and in the other, active survival. The degenerating nucleolar micronuclei become pycnotic and hence indistinguishable from non-nucleolar types. This must be the reason for their diverging frequency after 2 days (table 2, graph 3 ). It also explains the discrepancy between the relative frequency of the two types of acentric and that of their corresponding micronuclei at this time.

One further discrepancy is shown in table 2. After MH treatment, $\mathrm{X}_{1}$ cells containing both types of acentric are more frequent than resulting daughter cells with both types of micronuclei. This may be due partly to the segregation of the two types into separate daughter cells at $\mathrm{X}_{1}$ mitosis and partly to the formation of single micronuclei by both types.

The physiology of survival in micronuclei.-During the resting stage following $\mathrm{X}_{1}$ mitosis (after $\mathrm{MH}$ ), some excluded nucleolar acentrics evidently remain viable since 69.2 per cent. of their micronuclei become actively synchronised with the main nucleus at subsequent prophases (fig. $4^{e}$ and $f$; plate, fig. 4 , table 2 ).* The remaining 30.8 per cent. may possibly play a minor role in cell metabolism but are evidently incapable of mobilising their proteins, nucleic acids and other components in order to become effective working units. There is consequently no further visible reproduction of their constituent acentrics and they eventually die (fig. $4 d$ ).

We must now examine the three components which may control the balance between survival and death :-

(i) Euchromatin.-This is present in varying amount in all acentrics, micronuclei and main nuclei. Unlike the nucleolar organisers and heterochromatin it cannot be eliminated from any one of them by localised breakage and hence its relative functions are uncertain. It can, of course, be segregated alone in some micronuclei but these are inert and soon degenerate.

(ii) Nucleolar organisers.-The active survival of micronuclei is dependant on their containing a nucleolar organiser. La Cour (1952) found this to be true in Hyacinthus. In Vicia we can determine the relative parts played by nucleolar organisers and heterochromatin since they are to some extent separable by breakage.

(iii) Heterochromatin.- The amount of heterochromatin which is carried into the micronucleus is known to be variable. It depends directly on the position of breakage and on the type of reunion (figs. I and 2).

All nucleolar micronuclei are formed by acentrics derived entirely or in part from breakage in the nucleolar arm of the $\mathbf{M}$ chromosome. The combined evidence from cold treatment and breakage with

* Acentrics derived from EOC breakage are rarely viable (see table I). 
MH has shown that this arm carries one of the largest blocks of heterochromatin in the Vicia nucleus-corresponding with breakage segment 2-and possibly two smaller blocks corresponding with breakage segments $I$ and 3 (fig. 3 ). There may be additional smaller blocks which have so far eluded detection since numerous tiny chromocentres can occasionally be resolved in the micronuclei (fig. $4 d$ ).
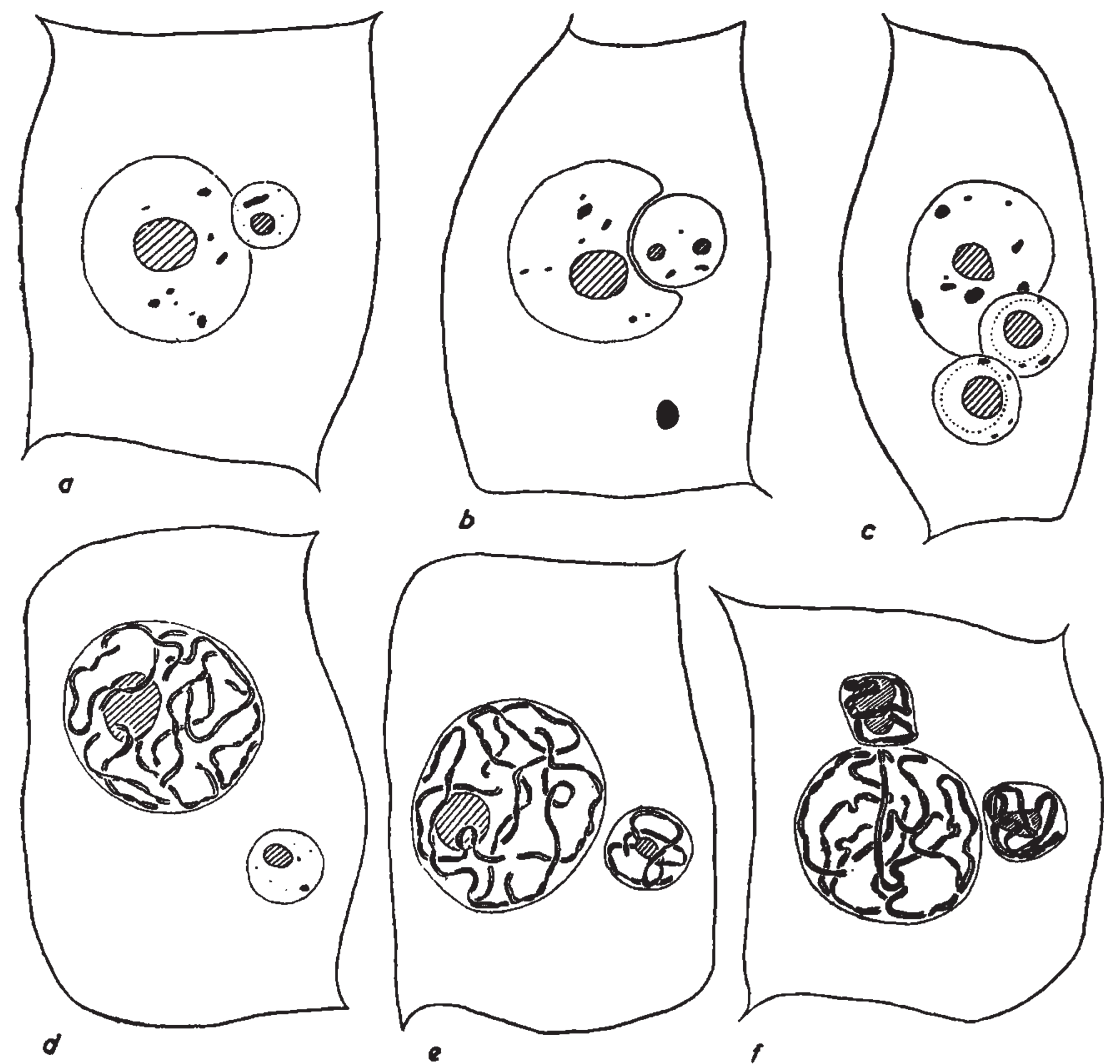

Frg. 4.-(a) to $(f)$. Root cells of Vicia faba containing micronuclei (m.n.) at different times after MH treatment.
(a) 24 hrs. : main nucleus and m.n. containing heterochromatin (black) and nucleoli (hatched).
(b) 48 hrs.: nucleolar m.n. partially enclosed by main nucleus. Small pycnotic m.n. degenerating in cytoplasm.
(c) 72 hrs. : 2 nucleolar m.n. A third nucleolus in the main nucleus.
(d) 72 hrs. : Active main nucleus at prophase. Inert nucleolar m.n. deficient in heterochromatin.
(e) 72 hrs. : Main nucleus and nucleolar m.n. synchronised at prophase.
(f) $92 \mathrm{hrs.:} \mathrm{Main} \mathrm{nucleus} \mathrm{and} \mathrm{nucleolar} \mathrm{m.n.} \mathrm{synchronised} \mathrm{at} \mathrm{prophase.}$
nucleolar m.n. $\times 1300$.

Even allowing for the possibility of fusion, the largest block must form one of the most prominent chromocentres in the resting nucleus. Yet, during resting stage 24 hours after treatment, only $44^{\circ} 4$ per cent. of nucleolar micronuclei contained chromocentres which appeared to be of comparable size. 
This may represent the proportion which remains viable. For, later on, of the $30 \cdot 8$ per cent. which were inert at $\mathrm{X}_{\mathrm{n}}$ prophase, only 2 contained such large chromocentres; Io had small to mediumsized chromocentres and 4 had none at all. Evidently, heterochromatin was the balancing factor for viability.

However, one inert micronucleus contained a nucleolus, 3 large and 3 medium-sized chromocentres. It apparently had all the requirements for activity-adequate heterochromatin and at least one nucleolar organiser-and yet was inert. Possibly, a non-nucleolar acentric, carrying the extra heterochromatin, had been included along with the nucleolar acentric. If this was the case, it would then appear that for activity, the nucleolar acentric must carry its own requirements of heterochromatin. The presence of a small amount near the nucleolar organiser which I previously inferred from breakage

TABLE 3

Localisation of the total breakage and reunion occurring up to 28 days after MH treatment in cell generations after $X_{1}$. High $R^{\prime}$ values are due to the reunion of broken ends from $X_{1}$ with deferred $B^{\prime}-s$ (see fig. 8 ). As at $X_{1}$, unreunited ends are rare. Reproduced in graph 5

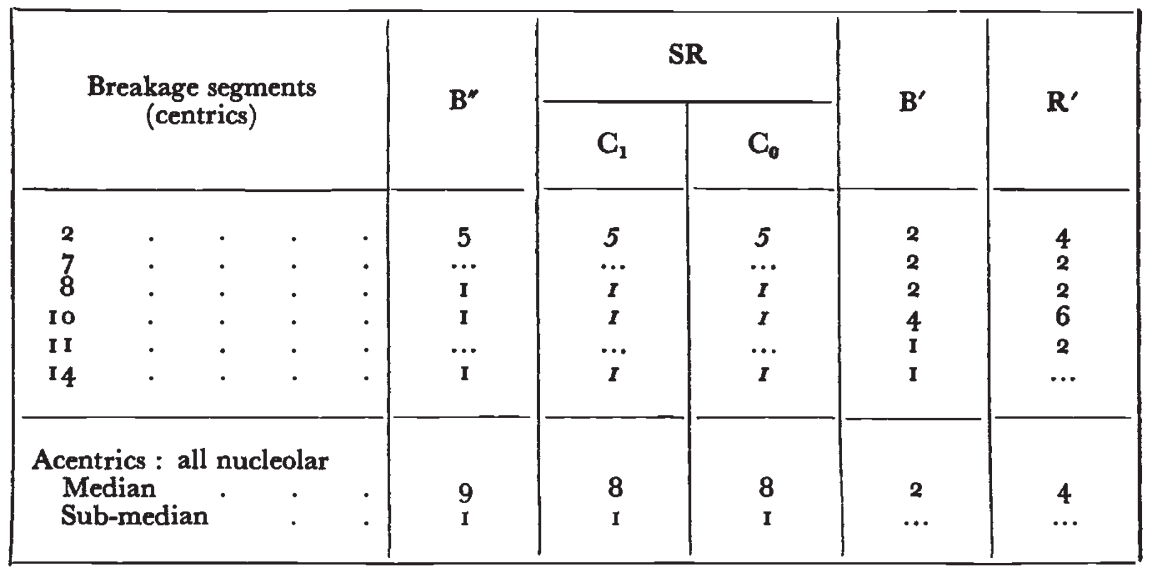

in segment $I$ is apparently not enough. Although short acentrics derived from breakage in this segment can occasionally reproduce, I think they do so only after inclusion in the main nuclei.

Supporting evidence that heterochromatin is the decisive factor for the survival of nucleolar micronuclei, comes from the localisation and frequency of deferred breakage. This, as we shall see, occurs at $\mathrm{X}_{2}$ and $\mathrm{X}_{3}$ following $\mathrm{MH}$ treatment. Breakage in these cells is more frequent in the middle of the nucleolar iso-acentric than in segment 2 of the remaining normal $\mathrm{M}$ chromosomes (table 3, graph 5, fig. $5 b)$. Breakage frequency seems to be roughly proportional to the size of heterochromatic segments as it is at $X_{1}$ (McLeish, 1952). Thus it follows that the segment in these nucleolar iso-acentrics must be as large, if not larger, than the segment in the $\mathbf{M}$ chromosomes. 
It may be lengthened as a result of duplication by SR (fig. 2). This would also account for the long rod-like chromocentres which can sometimes be seen in micronuclei (fig. $4 a$ ).

These cells are, of course, a selected sample. The acentrics can reproduce because of their large content of heterochromatin, yet it is through this heterochromatin that they are more susceptible to breakage.

From their study of the B chromosomes in Sorghum, Darlington and Thomas (I94I) have suggested that the effect of heterochromatin is to stimulate nuclear and hence cell division. Further, Caspersson et al. (see Caspersson, I950) have shown that heterochromatin and

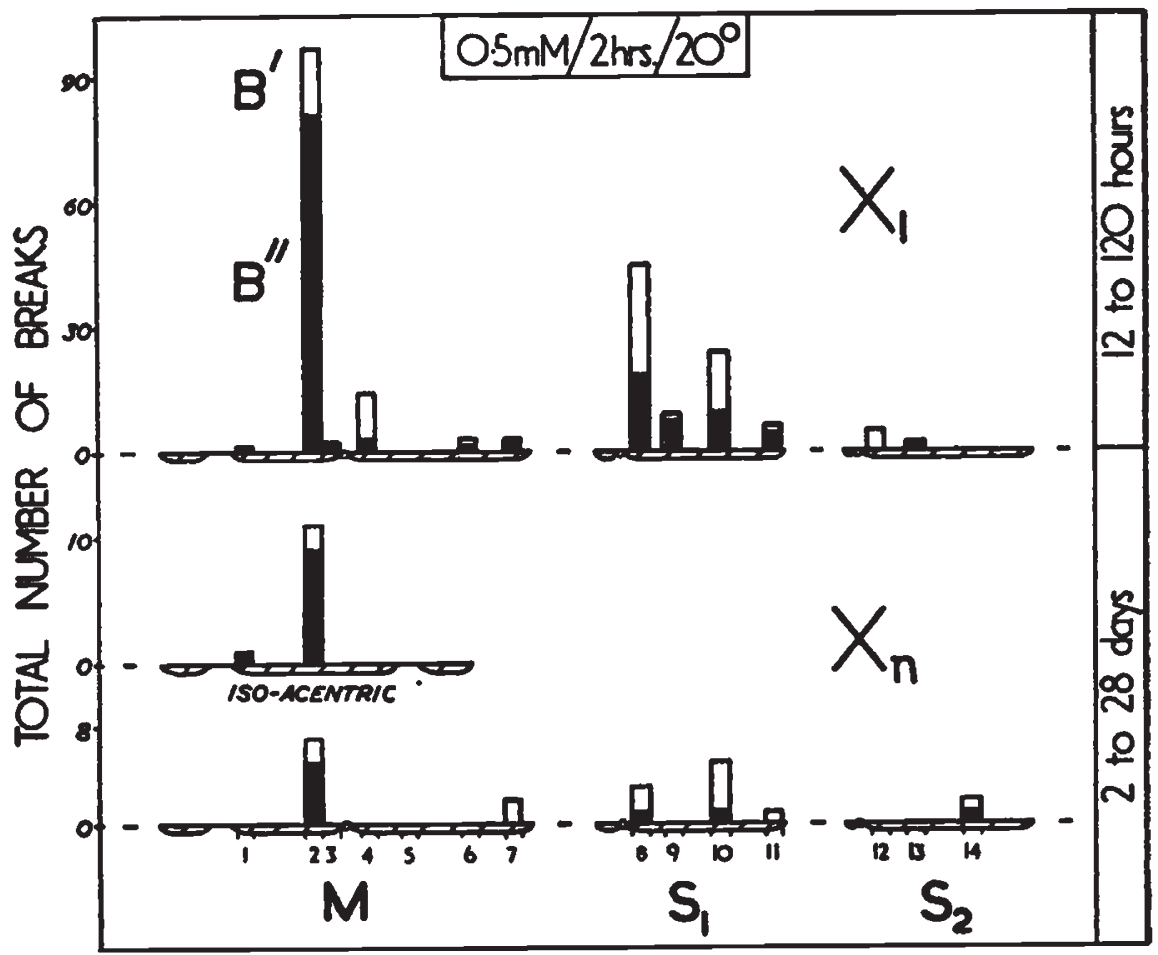

GRAPH 5.-Distribution of the segments (numbered $I$ to $r_{4}$ in the 3 chromosome types $M$, $S_{1}$ and $S_{2}$ ) in which primary breaks $\left(\right.$ at $X_{1}$ ) and deferred breaks (at $X_{n}$ ) occur after MH treatment. The change in the relative breakage frequencies in nucleolar and non-nucleolar chromosome arms in $\mathbf{X}_{\mathbf{n}}$ cells is not significant. From table 3 and McLeish (1952), table 4.

nucleoli are chemically inter-related; they appear to share similar functions in the protein and nucleic acid metabolism of the cell. The present results confirm the importance of their physiological relationship for chromosome reproduction and the working existence of the nucleus.

Nuclear co-operation.-The studies of Barber (194I) in Uvularia have shown how complementary and physiologically active resting nuclei can co-operate to make a balanced system in the cell. 
In Vicia the close association of a main nucleus with a nucleolar micronucleus often gives us an indication of their co-operation and of their impending synchronisation in mitosis. Non-nucleolar types seem never to be associated or synchronised with main nuclei in this way.

In 14.5 per cent. of cases, the nucleolar micronucleus is partially enveloped by the main nucleus (fig. $4^{b}$ ). Yet the two remain distinct with a clear dividing zone and do not fuse. This must be due to the fact that nuclei are bounded by real membranes and not merely

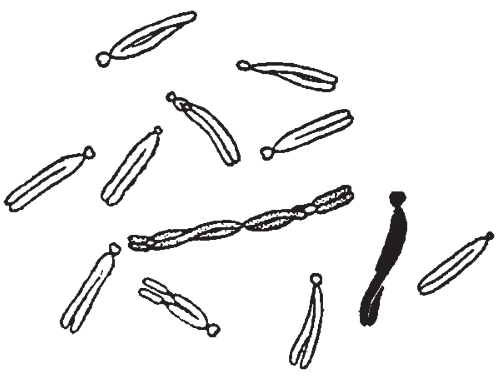

$\boldsymbol{\sigma}$

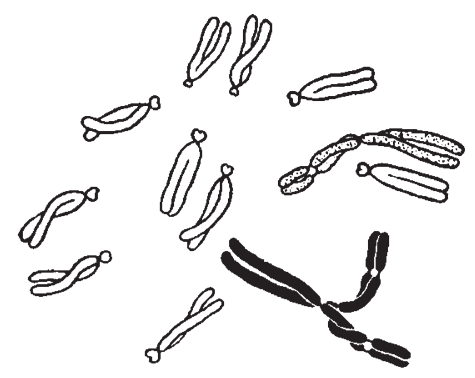

c

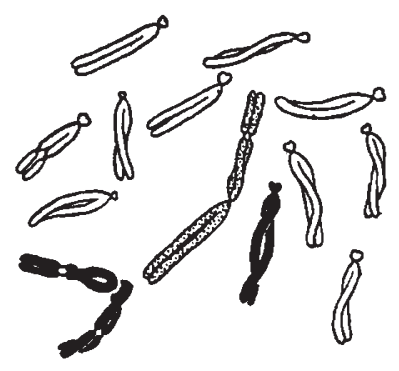

$\boldsymbol{b}$

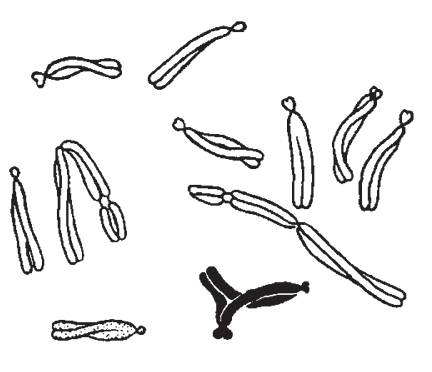

$\boldsymbol{d}$

FIG. $5(a)$ to $(d)$.-Metaphase cells derived from the $\mathrm{X}_{1}$ generation following $\mathrm{MH}$ treatment. Showing fragment chromosomes (black) and their homologues (stippled where recognisable).

(a) Cell deficient in the nucleolar arm of one $\mathbf{M}$ chromosome. The other $\mathbf{M}$ and two $\mathrm{S}_{1}$ chromosomes show partial breakage.

(b) $\mathbf{X}_{2}$ cell with reproduced nucleolar iso-centric with deferred $\mathbf{B}^{\prime \prime}+\mathrm{SR}$.

(c) Deferred breakage and reunion, involving an $\mathbf{M}$ chromosome and a nucleolar acentric, giving a triradial.

(d) An $\mathrm{S}_{1}: \mathrm{S}_{2}$ triradial. No fragment present. $\times 1250$.

surfaces (Callan and Tomlin, 1950; Bovey-see Wilkins, 1951). Dowrick (1954) has seen a similar situation in pollen grains of the diploid pear, Beurré Bedford. They contain groups of nuclei which remain closely associated but never fuse until mitosis when the membranes have gone.

In Vicia the close nature of the relationship between main nucleus and micronucleus is shown by the way they react to the loss or gain of nucleolar organisers. Evidently, the loss of one organiser from the nucleus and the cell does not impede mitosis since I have observed 
29 metaphases deficient in the nucleolar arm of one $\mathbf{M}$ chromosome (fig. 5a). But if both organisers are lost, it seems that no further mitosis can occur. If, however, both organisers are lost from the nucleus but included in the cell in micronuclei, a balanced system can result. Then the main nucleus is helped along by its two accessory nuclei and all three co-operate during the resting stage to achieve synchronisation at mitosis (fig. $4 f$ ).

This raises a further question. Why is it that a balanced micronucleus can help a deficient main nucleus and yet a balanced main nucleus cannot help a deficient micronucleus? The answer may lie in the fact that these micronuclei differ from main nuclei in one constant respect : they never contain centromeres.

We know that apart from its well-known function on the mitotic spindle, the centromere can be distinguished by its earlier behaviour inside the nucleus. It is known to influence the localisation of X-ray and ultra-violet radiation breakage as well as the frequency of sister reunion (Sax and Mather, I939; Swanson, I942 ; Darlington and Upcott, I 941 ; Darlington and La Cour, 1945). In Scilla, Rees (1952) has shown how it interferes with X-ray-induced errors of chromosome separation at anaphase.

In the absence of nucleolar organisers and detectable heterochromatin, centric chromosomes can form viable micronuclei in Uvularia (Barber, loc. cit.). Here, as in the case just described in Vicia, nucleolar organisers were present in the accompanying nucleus.

Thus the absence of heterochromatin or nucleolar organisers or both reveals that the centromere can play a part in maintaining the viability of a nucleus. This nucleus is then capable of co-operating in development with one or more complementary nuclei.

\section{REPRODUCING ACENTRICS AS CYTOLOGICAL MARKERS}

After $\mathrm{MH}$ treatment, some acentric fragments survive and reproduce through successive mitoses in viable micronuclei as can all types by inclusion in main nuclei. They all provide markers for timing the deferred breakage and reunion which continues to arise from the persistent effects of initial treatment.

Nucleolar acentrics were originally reported as reproducing in Vicia by Levan and Lotfy (I95I). They occur frequently in the present experiments and provide the most reliable markers (plate, fig. 6). Occasionally they can be studied in $X_{2}$ and $X_{3}$ prophase micronuclei. They appear to be able to reproduce through two successive mitoses ; an original acentric chromatid gives four chromatids in two pairs (fig. 6). The paired chromatids often show relational coiling. At $\mathrm{X}_{2}$ anaphase they rarely fall far apart and are both included in one of the daughter cells. Thus a further reproduction is an accurate indication of $\mathrm{X}_{3}$.

I have no evidence of their ability to undergo a further reproduction 
at $\mathbf{X}_{\mathbf{4}}$. By this time, the cells may have become unbalanced. Many will also have passed into differentiated tissue. In either case, they will not undergo mitosis again.

\section{DEFERRED BREAKAGE}

Initial treatment with $\mathrm{MH}$ causes breakage at $\mathrm{X}_{1}$ and in succeeding cell generations. It occurs at $\mathrm{X}_{2}$ and $\mathrm{X}_{3}$ with similar type and distribution as at $\mathrm{X}_{1}$ but with diminishing frequency (tables 3 and 4 ; graph 5, fig. 6). It occurs in hitherto undamaged chromosomes, in centric fragment chromosomes and in acentric chromosomes which have survived either by inclusion in main nuclei or through viable

TABLE 4

Frequencies of cells in secondary lateral roots of Vicia faba, showing primary and deferred breaks at different times after $M H$ treatment. Some cells can be timed in relation to the initial breakage (see text). The history of normal cells cannot be determined since they are unmarked

\begin{tabular}{|c|c|c|c|c|c|c|c|c|c|}
\hline \multirow{3}{*}{ Time } & \multirow{3}{*}{ Cells } & \multirow{3}{*}{ Normal } & \multicolumn{7}{|c|}{ Broken } \\
\hline & & & \multirow{2}{*}{$X_{1}$} & \multicolumn{2}{|r|}{$\mathbf{X}_{2}$} & \multicolumn{2}{|r|}{$\mathbf{X}_{3}$} & \multicolumn{2}{|c|}{ Untimed $\mathbf{X}_{\mathbf{n}}$} \\
\hline & & & & Total & Rebroken & Total & Rebroken & Total & Rebroken \\
\hline $2 \mathrm{D}$ & 200 & 125 & 72 & 3 & $\ldots$ & $\ldots$ & $\ldots$ & . & A \\
\hline $3 \mathrm{D}$ & 315 & 219 & $6 \mathrm{I}$ & 15 & 3 & $\ldots$ & $\ldots$ & $\dddot{20}$ & $\dddot{I}$ \\
\hline $4 \mathrm{D}$ & 266 & 164 & 35 & 34 & 7 & 4 & 2 & 29 & 4 \\
\hline $\begin{array}{l}5 \mathrm{D} \\
6 \mathrm{D}\end{array}$ & $\begin{array}{l}63 \\
65\end{array}$ & $\begin{array}{l}4^{6} \\
50\end{array}$ & $\begin{array}{l}4 \\
2\end{array}$ & $\begin{array}{l}8 \\
5\end{array}$ & $I$ & $\dddot{2}$ & $\dddot{x}$ & 5 & 2 \\
\hline ro D & 28 & 19 & I & 3 & $I$ & $\ldots$ & $\ldots$ & 5 & $I$ \\
\hline $19 \mathrm{D}$ & 18 & 12 & $\ldots$ & 3 & 2 & I & $\ldots$ & 2 & $I$ \\
\hline $28 \mathrm{D}$ & 30 & 24 & 2 & 2 & $\ldots$ & $\ldots$ & $\ldots$ & 2 & $\ldots$ \\
\hline
\end{tabular}

micronuclei (figs. 5 and 6). Furthermore, $\mathrm{X}_{1}$ and $\mathrm{X}_{2}$ breakage reappears in newly formed tertiary roots 28 days after treatment.

Deferred breakage may be the later expression of the partial breakage seen at $\mathbf{X}_{1}$. Particularly if, as Darlington (1950) suggests, the chromosome has a multiple fibre structure. For breakage occurring in a few of these sub-units would not become effective in the whole chromosome until they had been sorted out in successive mitoses.

An alternative and more likely explanation is that the reagent persists in the cells for a long period, where it continues to induce its characteristic action in the chromosomes. In view of its molecular structure, which has been discussed by Kihlman (I95I), Loveless (1952) and others, it could conceivably be incorporated in the cell in some way to form a substitution nucleic acid precursor.

A further indication of its continued presence is its permanent effect on the size of the meristematic zone. This is gradually reduced 
in length during the first 3 days after treatment and often remains so for at least 28 days. Within this zone, however, mitosis continues at an approximately normal level. The effect on mitosis is probably,

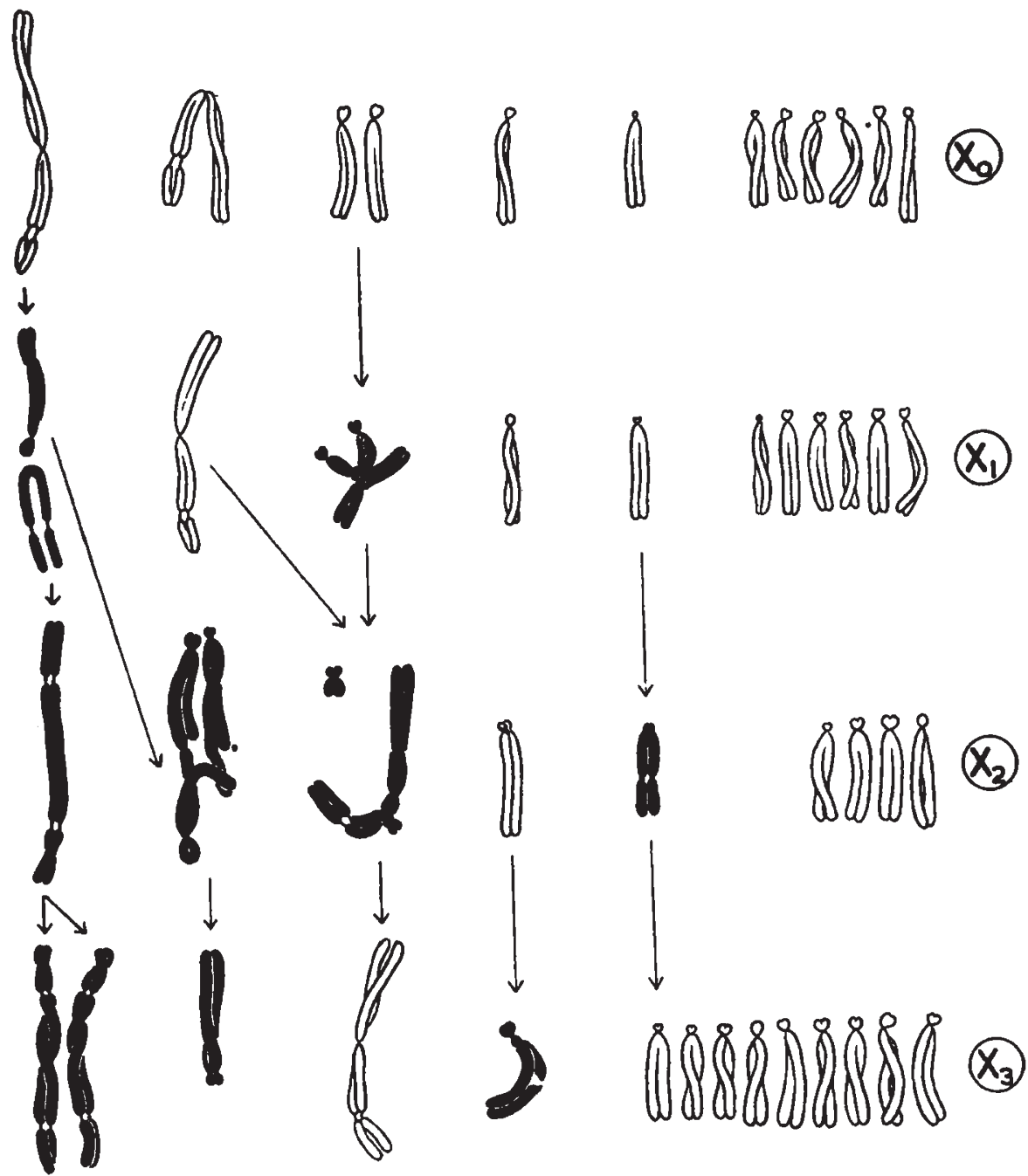

Frg. 6.-Metaphase chromosomes observed in a normal cell $\left(\mathrm{X}_{0}\right)$ and in 3 consecutive cell generations $\left(\mathrm{X}_{1}\right.$ to $\left.\mathrm{X}_{8}\right)$ after $\mathrm{MH}$ treatment. Illustrating some of the possible ways in which configurations formed at one mitosis can influence those formed at the next. $X_{2}$ and $X_{8}$ are timed in relation to $X_{1}$ by the number of reproductions of the nucleolar iso-acentric (left).

$\mathrm{X}_{1}, 48 \mathrm{hrs}$ : : $\mathrm{B}^{\prime \prime} \mathrm{SR}$ in segment 2 giving a nucleolar iso-acentric. $\mathrm{S}_{1}: \mathrm{S}_{1}$ interchange forming a $\mathrm{C}_{2}^{\prime}$.

$X_{2}, 96$ hrs. : fragment chromosomes from $X_{1}$ reunited with deferred breaks. Partial break in an $\mathrm{S}_{2}$ chromosome.

$\mathrm{X}_{3}, 96$ hrs. : Deferred $B^{\prime}$ in an $S_{1}$ chromosome. $\times 1250$.

as I pointed out previously, something different from the chromosome breaking effect. It could possibly be correlated with the findings of Leopold and Klein (195I) that MH is an anti-auxin. 


\section{SECONDARY REUNION}

The chief consequences of $\mathrm{X}_{1}$ anaphase separation, after $\mathrm{MH}$ treatment, are shown in fig. 8. Dicentric chromatid bridges resulting from SR or R' break at random. The two daughter nuclei then receive equal or unequal fragment chromosomes whose broken ends can behave in one of three ways :

(i) They can undergo $R^{\prime \prime}$ with other broken ends to give dicentrics (fig. $7 b$ ). This occurs in a restricted period of movement during telophase which has been defined by La Cour (1952).

(ii) If $R^{\prime \prime}$ does not occur before the initiation of the $\mathrm{X}_{2}$ mitosis, the broken ends then have the opportunity to undergo secondary or delayed SR (fig. 7a) as in the breakage-fusion-bridge cycle of McClintock (194I). In Vicia after MH treatment, as in Hyacinthus after X-raying (La Cour, I952), this is rare.
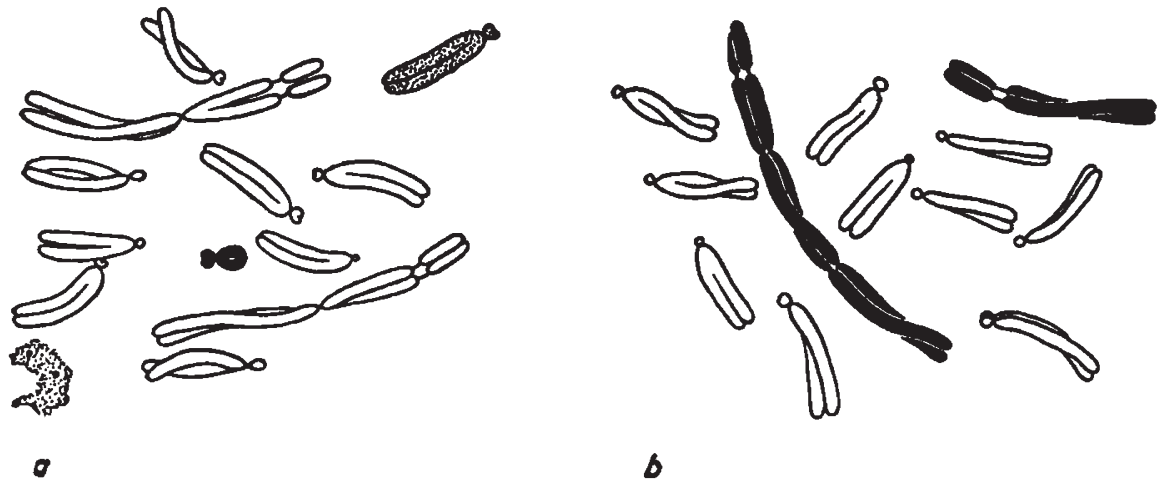

6

Fic. $7(a)$ and $(b)$.-Secondary reunion in $\mathrm{X}_{2}$ metaphase cells of Vicia $96 \mathrm{hrs}$. after $\mathrm{MH}$ treatment.

(a) $\mathrm{SR}$ in an $\mathrm{S}_{1}$ centric fragment; remainder of chromosome present as a micronucleus. Possible undamaged $S_{1}$ homologue stippled.

(b) $\mathrm{C}_{2}$ " derived from non-homologous $\mathrm{R}^{\text {" }}$ between the broken ends of two $\mathrm{M}$ fragment chromosomes carried through from $\mathbf{X}_{1}$. Nucleolar $\mathbf{C o}^{\prime \prime}$ formed by reproduction of an original $\mathrm{Co}^{\prime} . \quad \times 125^{\circ}$.

(iii) Finally, the residue of broken ends failing to undergo either $\mathbf{R}^{\prime \prime}$ or SR, remain open for a sufficient time to reunite with centric and acentric fragments which have suffered deferred breakage. Such reunion of new and old ends accounts for the common occurrence, at $\mathrm{X}_{2}$, of triradials (fig. $5^{c}$ and $d$ ).

This sequence of events shows SR to be a different type of reunion from either $R^{\prime \prime}$ or $R^{\prime}$. For, although the separate sister chromatid ends remain capable of reunion after the split, they do not seem to reunite with one another. Thus, it is easier to look upon SR as resulting earlier from failure of chromosome reproduction rather than later from a real reunion of sister chromatids.

An accurate quantitative assessment of these various types of secondary reunion is impossible for the following reasons :

(i) Dicentric chromosomes seen at $\mathbf{X}_{2}$ need not be the result of 
$\mathbf{R}^{\prime \prime}$. They can also arise by the subsequent duplication of complete dicentric chromatids which passed complete to one pole at $\mathrm{X}_{1}$ (fig. 8). (ii) The absence of SR in fragment chromosomes at $X_{2}$ is not necessarily an indication of its failure. Such small chromosomes can arise from chromatid translocation at $X_{1}$. Their breakage and reunion points are interstitial and consequently hidden and sealed against further reunion. (iii) In a somewhat similar way, the high frequency of

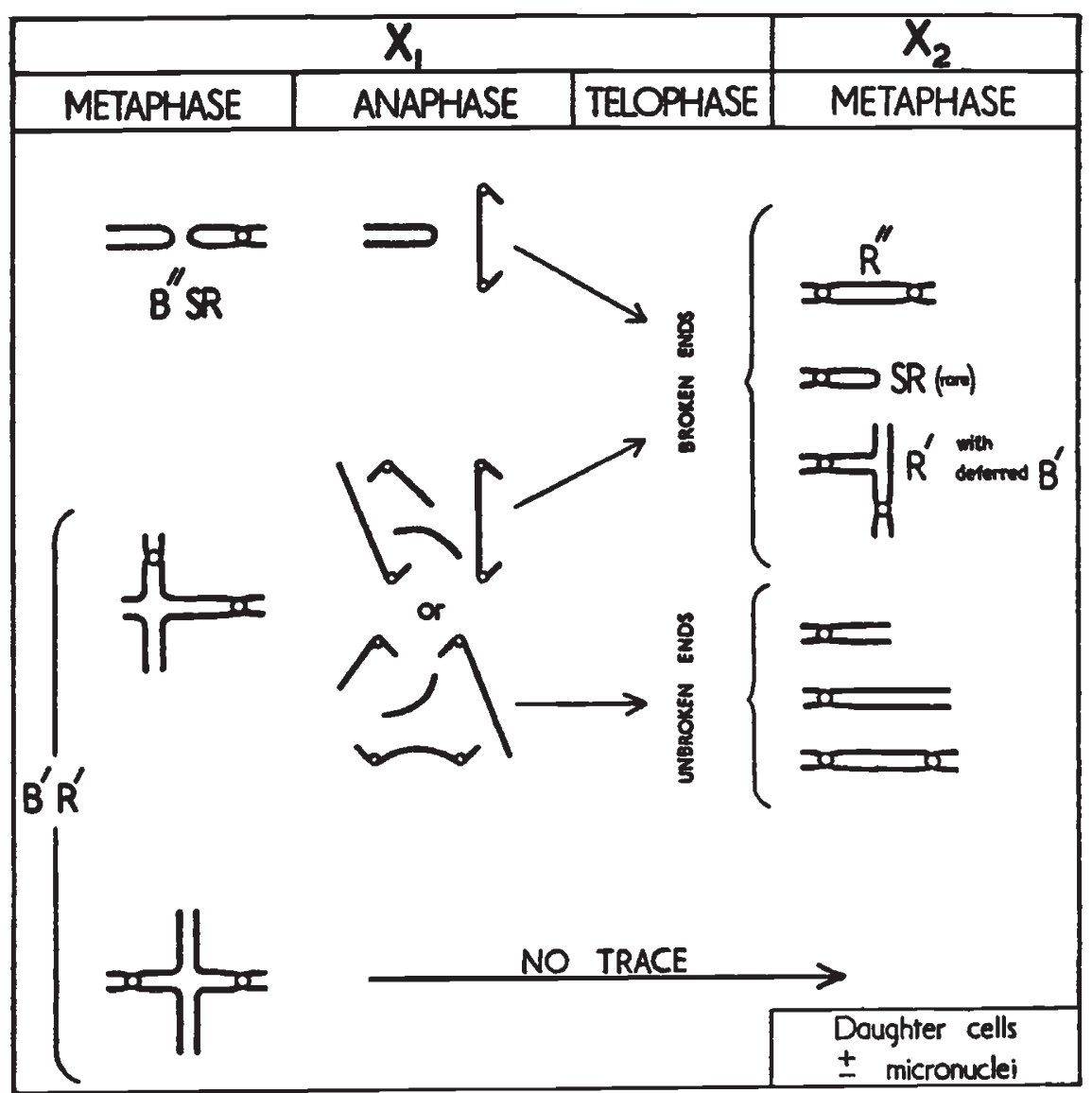

Frg. 8.-Typical $\mathrm{X}_{1}$ metaphase configurations seen after $\mathrm{MH}$ treatment and the chief consequences of their separations at anaphase. Derived $\mathbf{X}_{2}$ daughter cells may or may not contain micronuclei.

reunion in acentrics at $\mathbf{X}_{1}$ leaves few with broken ends (McLeish, 1952). Thus even if they are included in main nuclei, they are seldom involved in secondary reunion unless re-broken.

\section{SUMMARY}

I. Treatments with maleic hydrazide (MH) and 8-ethoxycaffeine (EOG) lead to specific and different patterns of chromosome breakage and reunion in Vicia faba. Standard types of centric and acentric fragments therefore enter into the main nuclei and the micronuclei. 
2. Acentrics and micronuclei can thus be classified into four types according to their combinations of euchromatin, heterochromatin and nucleolar organisers.

3. Nucleoli are organised in some micronuclei. As in the main nuclei, they appear to be formed on a specific chromosome segment, by an organiser at the proximal end of the secondary constriction. Their size is influenced by competition between their organisers and by the size of the nuclei.

4. Viable micronuclei have to carry both nucleolar organisers and heterochromatin. They co-operate with main nuclei during interphase and become synchronised with them during prophase. The nuclei, which have definite membranes, are often closely associated, but they rarely, if ever, fuse.

5. When included in main nuclei, all types of acentric can reproduce in successive mitoses $\left(\mathrm{X}_{2}, \mathrm{X}_{3}\right)$. Nucleolar types can also do so in micronuclei. They thus mark the number of the mitosis and show when deferred breakage and secondary reunion are taking place.

6. The regular pattern of breakage seen at $\mathrm{X}_{1}$ after $\mathrm{MH}$ treatment can thus be shown to be repeated in $X_{2}$ and $X_{3}$ cells for at least 28 days.

7. Broken ends in centrics and acentrics are carried through from $\mathrm{X}_{1}$ and $\mathrm{X}_{2}$. They can then reunite with contemporary, as well as with deferred, breaks. Moreover the reunions are of new kinds: at $\mathrm{X}_{1}-\mathrm{SR}$ but rare $\mathrm{R}^{\prime \prime}$; at $\mathrm{X}_{2}-\mathrm{R}^{\prime \prime}$, but rare $\mathrm{SR}$.

Acknowledgments. - I am indebted to Professor C. D. Darlington and Mr L. F. La Cour for their help and encouragement during the course of this work.

\section{REFERENCES}

barber, h. N. 1941. Chromosome behaviour in Uvularia. 7. Genet, 42, 223-257.

GALlaN, H. G., AND tOMLIN, s. G. 1950. Experimental studies on amphibian oocyte nuclei I. P.R.S., B, $137,367-378$.

CAspersson, T. 1950. Cell Growth and Cell Function. ist Ed. London : Chapman \& Hall.

Darlington, c. D. I950. Physical and chemical breakage of chromosomes. Pubbl. della Stazione Zool. di Napoli, 22 (Suppl.), 22-3 I.

DARLINGTON, C. D., AND HAQUE, A. I954. Breakdown of meiosis in Allium cepa. Heredity (in the press).

DARLINGTON, G. D., AND LA COUR, L. F. I940. Nucleic acid starvation of chromosomes in Trillium. 7. Genet., 40, $185-213$.

DARLINGTON, C. D., AND LA COUR, L. F. I94I. The detection of inert genes. 7 . Hered., 32, I I 5-121.

DARlington, C. D., AND LA COUR, L. F. 1945. Chromosome breakage and the nucleic acid cycle. 7. Genet., 46, i 80-267.

DARlington, c. D., AND ThOMAS, P. T. I941. Morbid mitosis and the activity of inert chromosomes in Sorghum. P.R.S., B, 130, 127-1 50.

DARLINGTON, C. D., AND UPCOTT, M. B. I 941 . Spontaneous chromosome change. 7. Genet., 4I, 297-338.

Dowrick, G. J. I954. Meiosis in Pyrus. I. The origin of polyploid gametes. Heredity (in the press). 


\section{Plate}

Fig. 1. $-\mathrm{X}_{1}$ anaphase after EOC. Breakage and reunion (probably B"SR) has occurred in the nucleolar constriction, part of which is now visible in the centre of the $\mathrm{C}_{2}{ }^{\prime}$ bridge and part in the centre of the $\mathrm{Co}^{\prime}$.

Figs. 2 to 5.-Reproduction of a balanced acentric after MH breakage.

2. $\mathrm{X}_{1}$ anaphase. Breakage and sister reunion $(\mathrm{B}$ "SR) in segment 2 has given a nucleolar iso-acentric and $\mathrm{a}_{2}{ }^{\prime}$. The undamaged sister $\mathrm{M}$ chromosomes have passed to the poles.

3. Daughter cell arising from a mitosis as shown in fig. 2. Nucleoli organised by the undamaged $\mathrm{M}$ chromosome in the main nucleus and by the nucleolar iso-acentric in the micronucleus.

4. Synchronisation of main nucleus and micronucleus at $\mathrm{X}_{2}$ prophase.

5. Early anaphase of $\mathrm{X}_{2}$. The original $\mathrm{Co}^{\prime}$ is now a Co".

Figs. 6 and 7.- $\mathrm{X}_{2}$ metaphases after $\mathrm{MH}$.

Fig. 6.- $\mathrm{B}^{\prime \prime} \mathrm{SR}$ probably occurred in segment 2 of both $\mathrm{M}$ chromosomes at $\mathrm{X}_{1}$. Both the resulting nucleolar iso-acentrics have reproduced (at 3 and 5 o'clock); one shows a median deferred break. The centric fragments have undergone $\mathrm{R}^{\prime \prime}$ to give a $\mathrm{C}_{2}{ }^{\prime \prime}$.

Fig. 7.-A non-nucleolar acentric (9 o'clock) derived from breakage in an $\mathrm{S}_{1}$ chromosome at $\mathrm{X}_{1}$ has reproduced by inclusion in a main nucleus. The centric fragment is lying in the centre of the cell.

All figures : $\times$ r8oo. 


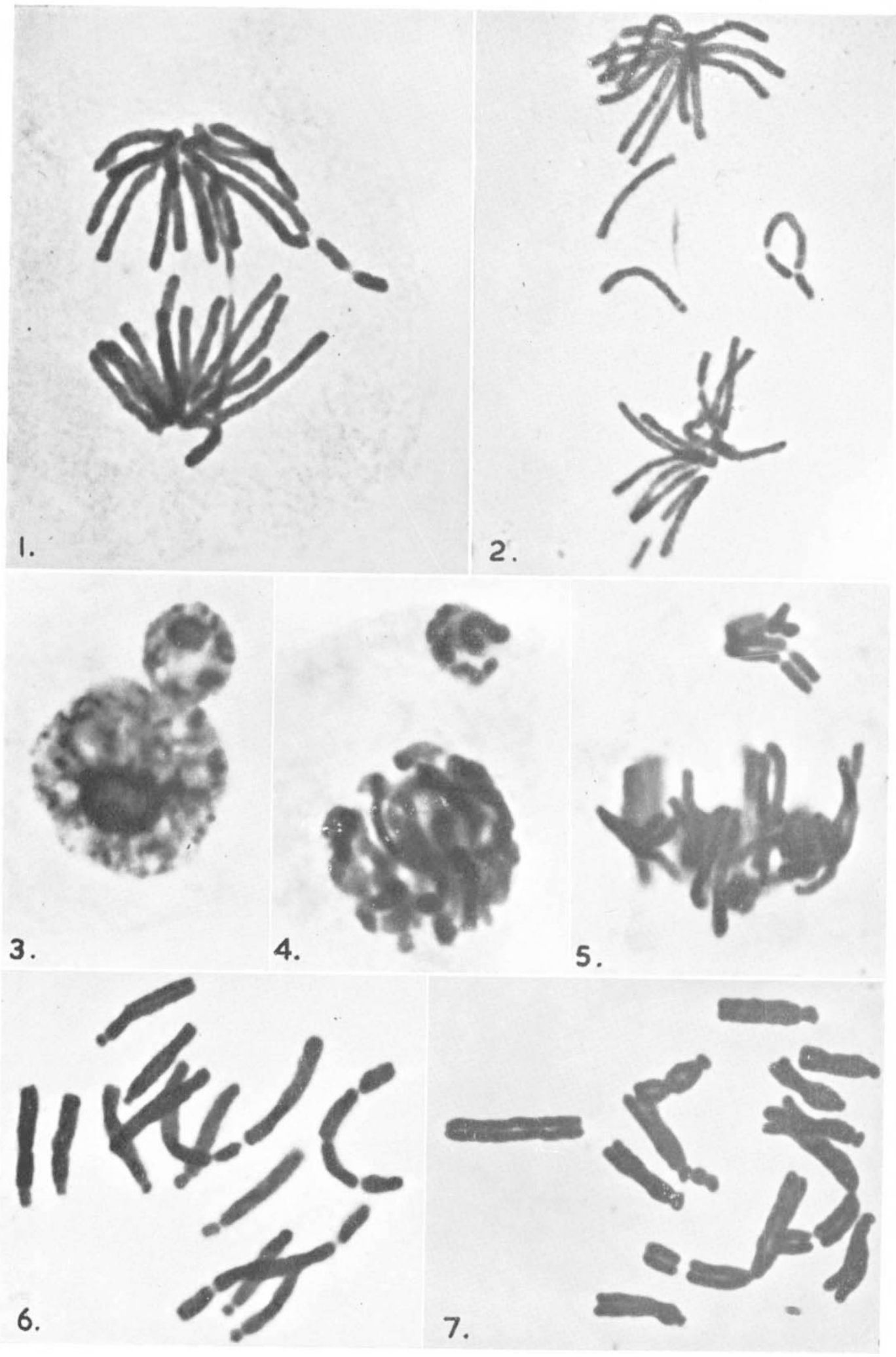


FERNANDES, A., AND SERRA, J. A. 1944. Euchromatine et Hétérochromatine dans leurs rapports avec le noyau et le nucléle. Bol. Soc. Broteriana, 19, 67-124.

HErTz, z. I 93 I. Nukleolen und chromosomen in der Gattung Vicia. Planta, 15, 495-505.

XIHLMAN, B. 1952. Induction of chromosome changes with purine derivatives. Symb. Bot. Upsal., II (4), I-99.

KIHLMAN, B., AND LEVAN, A. I951. Localised chromosome breakage in Vicia faba. Hereditas, 37, 382-388.

KURNICK, N. B. r952. Histological staining with methyl green-pyronin. Stain Tech., 27, 233-242.

LA COUR, L. F. I952. The physiology of chromosome breakage and reunion in Hyacinthus. Heredity, 6, Suppl., 163-1 79.

LEOPOLD, A. G., AND KLEIN, W. H. I95I. Maleic hydrazide as an anti-auxin in plants. Science, II 4 , 9-IO.

LEShER, S. I951. Studies on the salivary gland of Drosophila. II. Exptl. Cell Res., 2, 586-588.

LEVAN, A., AND LOTFY, T. I950. Spontaneous chromosome fragmentation in seedlings of Vicia faba. Hereditas, $36,470-482$.

LEWTISKY, G. A. I93I. An essay on cytological analysis of the fixing action of the chrom-acetic formalin and the chromic formalin. Bull. appl. Bot., 27 (I), I $8 \mathrm{I}-\mathrm{I} 85$.

LOVELEss, A. 1952. Chemical and biochemical problems arising from the study of chromosome breakage by alkylating agents and heterocyclic compounds. Heredity, 6, Suppl., 293-298.

MCGLINTOCK, B. 1934. The relation of a particular chromosomal element to the development of the nucleoli in Zea mays. Z. Zellforsch., 21, 294-328.

McCLINTOCK, B. I94I. The stability of broken ends of chromosomes in Zea mays. Genetics, 26, 234-282.

MCLEISH, J. 1952. The action of maleic hydrazide in Vicia. Heredity, 6, Suppl., I 25-I 47 .

NAVASHin, M. 1934. Chromosome alterations caused by hybridisation and their bearing upon certain general genetic problems. Cytologia, 5, 169-203.

REES, H. I952. Centromere control of chromosome splitting. Heredity, 6, Suppl., 235-245.

SAX, K., AND MATHER, K. 1939. An X-ray analysis of progressive chromosome splitting. 7. Genet., 37, 483-49o.

SEMmens, C. J., AND BHADURI, P. N. I94I. Staining the nucleolus. Stain. Tech., I6, I I 9-I 20.

swanson, c. P. I942. The effect of ultra-violet and X-ray treatment on the pollen tube chromosomes of Tradescantia. Genetics, 27, 491-503.

WILkINS, M. H. F. 195ז. Electron microscopy of nuclear membranes. Pubbl. della Stazione Zool. di Napoli, 23, Suppl., I $10-115$. 